\title{
Influence of Heat Treatment on the Change of Al-Si Coating Properties at Ultra-high Strength Sheets
}

\section{Michaela Kolnerova, Jiří Sobotka, David Koreček, Pavel Solfronk}

Faculty of Mechanical Engineering, Technical University of Liberec. Studentská 1402/2, 46117 Liberec

Czech Republic.E-mail: michaela.kolnerova@tul.cz,jiri.sobotka@tul.cz, david.korecek@tul.cz, pavel.solfronk@tul.cz

Paper deals with the evaluation of protective coating surface layer Al-Si at boron steel 22MnB5. Parts from these steels are used at the car-body design. Such parts are produced by hot forming technology that means not only higher requirements on material but also on the surface layer. Coatings are used to protect surface against oxidation during heating and also support the own forming process inside the tools. In this paper is evaluated the protective layer change during heat treatment - heating in furnace (8, 12 and 16 min). Performed microscopic analysis of $\mathrm{Al}-\mathrm{Si}$ surface layer proves the thermal regime influence on the change of coating properties.

Keywords: Heat Treatment, 22MnB5, AlSi Coating, Surface Layer, AHSS

\section{Introduction}

Vehement development of the automotive industry during the last years has introduced, among others, utilization of the newly developed types of materials which have their importance for the car-body design in light of material processing, car-body weight reduction and thus also fuel consumption. However, as the crucial factor there is safety of passengers which is influenced by the design and used materials. These days are most car-body parts produced from steel. Classification of steels can be done acc. to many aspects and own utilization depends also on type of stamping. Beside the common deep-drawing sheets there are used also e.g. low-strength steels (LSS), high strength steels (HSS) and during last year are applied also "advanced" ultra-high strength steel (AHSS) $[1,2]$. At new models of cars are in critical car-body zones used ultra-high strength steel sheets. As one of these materials there is ultra-high strength steel 22MnB5 that is also hot forming steel. Hot forming of car-body panels (mechanical-heat treatment) is relatively new technology, which fulfills requirements about car-bodies to have higher stiffness and simultaneously favourable weight.

\section{Ultra-high strength hot forming steel 22MnB5}

This ultra-high strength steel is alloyed by boron that provides the martensitic structure. It is cold rolled steel, which is suitable for quenching and tempering and has high ultimate strength and very good formability. This steel is used mainly at products which require good formability after their processing and high strength of the final part. Required strength and hardness is at these steels achieved by simultaneous forming and heat treatment (quenching is performed inside the forming tool) - that is why these steels are termed as hot forming steels (HF) [3, 4].

Ultra-high strength steel $22 \mathrm{MnB} 5$ is used in the automotive industry mainly for the car-body safety elements as can be e.g. bumper reinforcement, A and B-pillars, side panels reinforcement, doors, doorsills and so on (see Fig. $1)$.

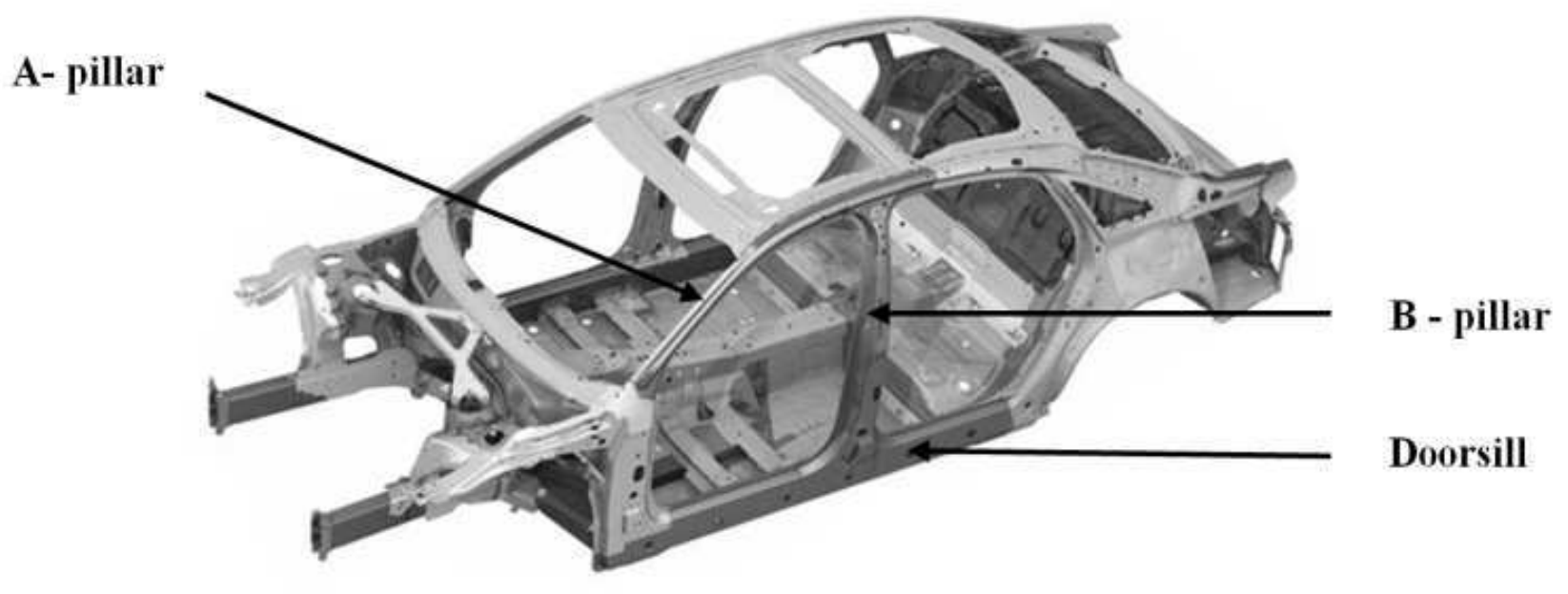

Fig. 1 A and B-pillar, doorsill of Audi A8 [5] 
As a major advantages of hot forming steel $22 \mathrm{MnB} 5$ there are: [6]

- very good hot formability makes possible to produce difficult geometries of parts,

- removal of reinforcement parts and assemblies,

- total absence of sheet spring-back,

- uniform mechanical properties through the whole part,
- extraordinary fatigue strength and impact resistance allows to reduce weight.

Steel $22 \mathrm{MnB} 5$ is very suitable for so-called "quenching by forming". This property is given by adding the small amount of boron. Thus because of that are these steels also called as "Boron steels". Chemical composition of tested material is given in Tab. 1.

Tab. 1 Chemical composition [wt\%] of tested steel 22MnB5 [7]

\begin{tabular}{|c|c|c|c|c|c|c|c|c|c|c|c|}
\hline $\mathrm{C}$ & $\mathrm{Si}$ & $\mathrm{Mn}$ & $\mathrm{P}$ & $\mathrm{S}$ & $\mathrm{Al}$ & $\mathrm{B}$ & $\mathrm{Cr}$ & $\mathrm{Cu}$ & $\mathrm{Mo}$ & $\mathrm{Nb}$ & $\mathrm{Ti}$ \\
\hline 0.201 & 0.226 & 1.13 & 0.01 & 0.0005 & 0.033 & 0.002 & 0.187 & 0.011 & 0.001 & 0.001 & 0.034 \\
\hline
\end{tabular}

Tab. 2 Mechanical properties of steel 22MnB5 [7]

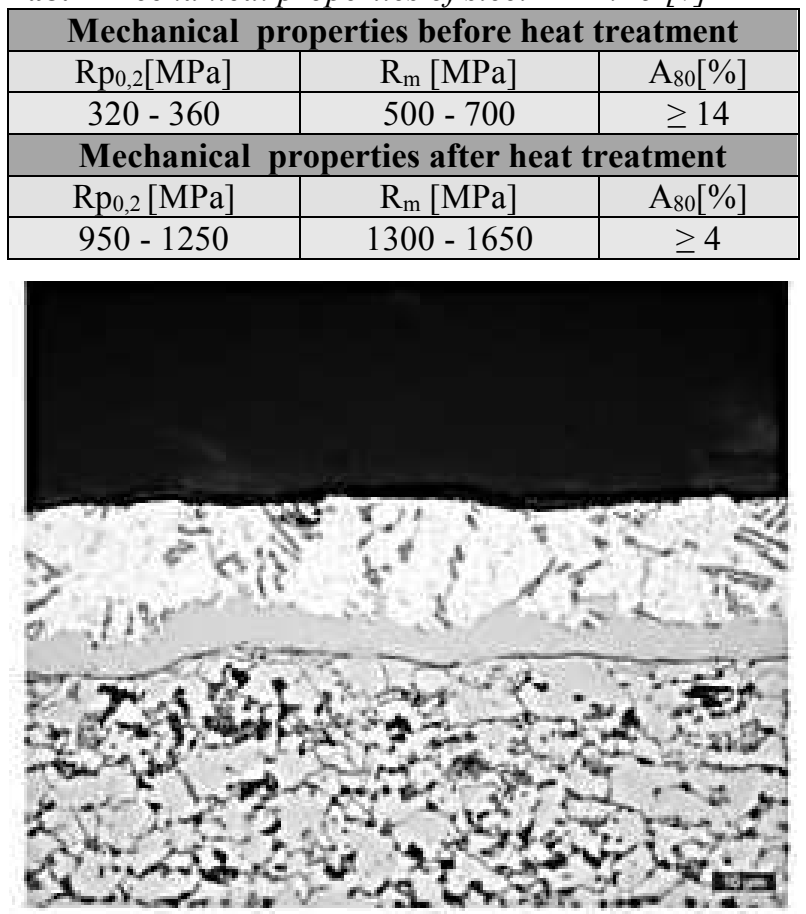

a)
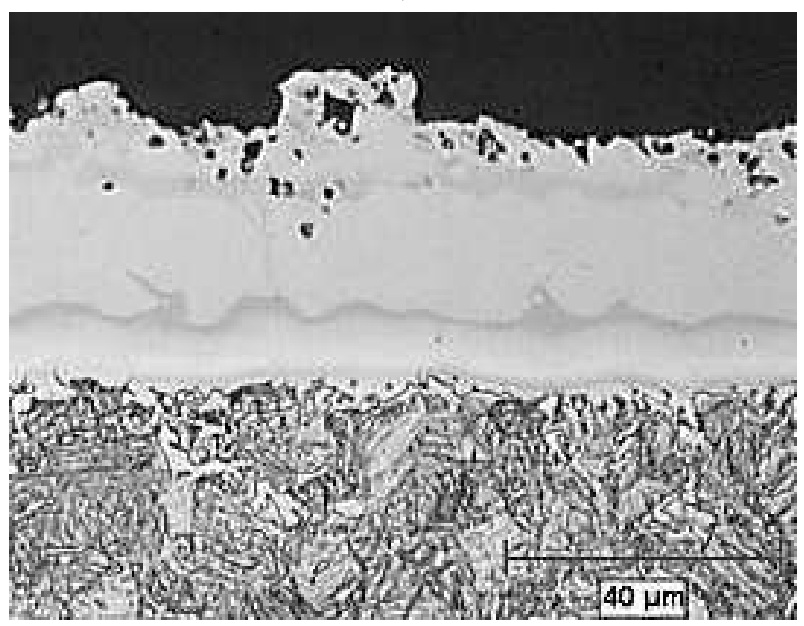

b)

Fig. 2 Structure of material a) before quenching and forming, b) after quenching and forming [6]
Mechanical properties magnitudes are closely connected with the production technology - mainly on the rolling method (cold or hot rolling) and whether there is coating or not. Mechanical properties of tested steel $22 \mathrm{MnB} 5$ with thicknesses 1,00 - 1,25 mm are summarized in Tab. 2.

Internal material structure before quenching and stamping is the ferritic-perlite one (see Fig. 2a). This structure during heating transforms on the austenitic one, which has a very good formability. After quenching and forming, structure transforms on the fully martensitic one with the residual austenite (see Fig. 2b) [8].

\section{Protective coating Al-Si}

Coating Al-Si serves as a protective layer for sheet blanks against oxidation and decarburization during the hot forming process - both during heating in furnace and during sheet transport into forming tool and subsequent forming and quenching in the mould. Al-Si coatings are applied by the hot dip galvanizing method.

Chemical spectrum of the surface layer is as following: $88,73 \% \mathrm{Al}, 10,31 \% \mathrm{Si}$ and $1,96 \% \mathrm{Fe}$. Coatings of this chemical composition have the melting temperature about $600^{\circ} \mathrm{C}$ and due to the austenitizing of material there is needed to get over it. During the heating in furnace takes effect the diffusion of elements from the basic material into the surface layer and vice-versa. It results in increasing iron content in the layer and subsequent creation of compounds with the

$\mathrm{Al}-\mathrm{Fe}$ basis $\left(\mathrm{FeAl}_{3}\right.$ or $\left.\mathrm{FeAl}\right)$ on the boundary between layer and basic material. These compounds have much higher melting temperature than original coating and transfer on the coating surface where prevent the surface layer from melting.

Sheets with the surface coating on the Al-Si basis are not possible to be processed by indirect method [6]. It is due to fact that compounds Al-Fe have much worse formability than basic material that has ferritic-perlite internal structure.

Al-Si coatings should have thickness about $30-40 \mu \mathrm{m}$. Coating is not homogenous through the whole crosssection (see Fig. 3), but it consists of several layers in dependence on the technological conditions during its production. 


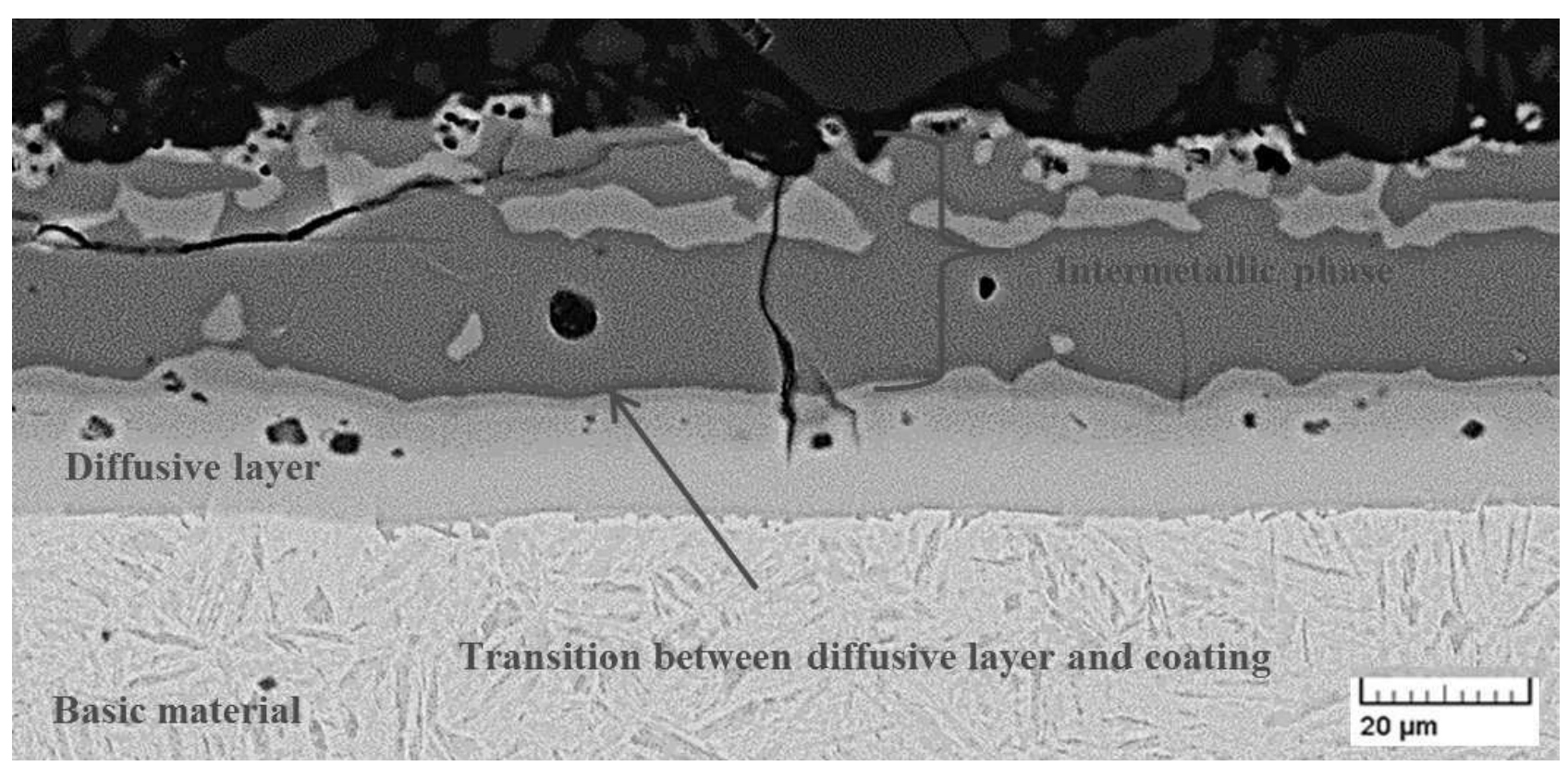

Fig. 3 Section of Al-Si layer after heat treatment [9]

Coating doesn't have the homogenous chemical composition through the whole thickness that results in very poor weldability of these sheets $[4,10,11]$. If there is longer austenitizing time, there is intermetallic layer growing and creation of sub-layer which is enriched by iron. Simultaneously, there is increase in oxides thickness on the coating surface that results in surface color change due to the different interference of these oxides (higher Al content in the surface layer). Because of that, there is possible to look on the quality and composition of coating in light of its color shadow. In Fig. 4 are shown examples of sheet surface layers in dependence on the heat treatment time and temperature.

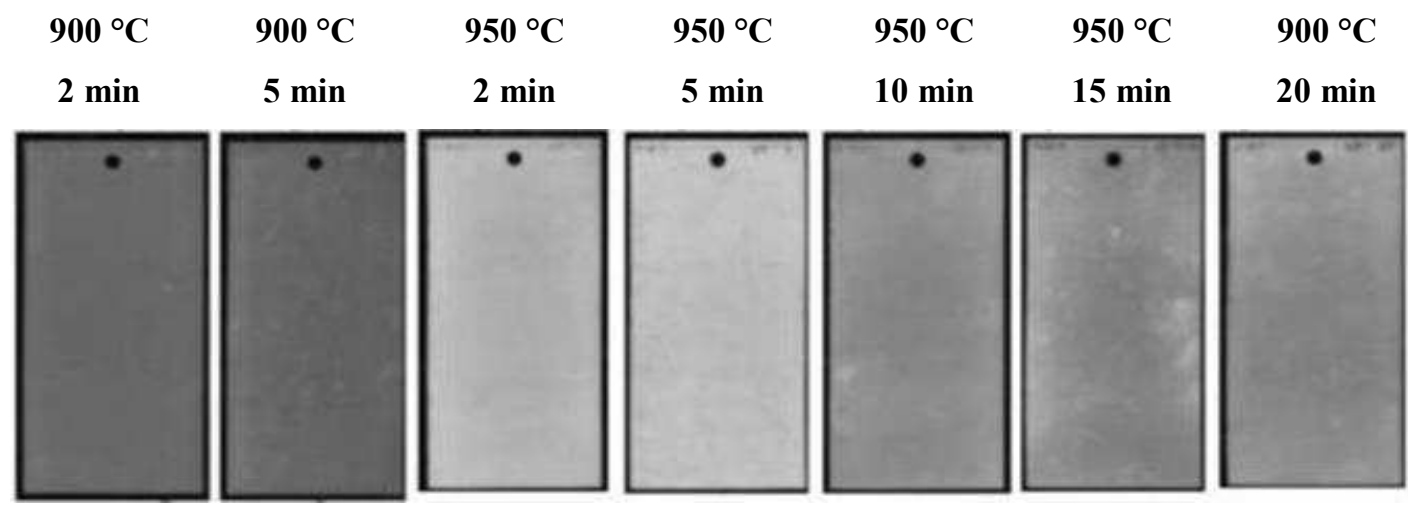

Fig. 4 Color shades of surface layer after heat treatment [9]

\section{Analysis of surface layer Al-Si}

As a substrate for tests there was used material $22 \mathrm{MbB} 5$ with hot dip galvanized protective surface layer Al-Si of amount $79 \mathrm{~g} \cdot \mathrm{m}^{-2}$ - it corresponds to the material indication AS 150. This material was subsequently heat treated. Prepared samples were placed into the electrical furnace which was pre-heated at temperature $900^{\circ} \mathrm{C}$. To completely heat up the samples, times for their placing in furnace were as following: 8, 12 and $16 \mathrm{~min}$. Subsequently were samples quenched [9].

In Fig. 5 are shown the color shades after individual intervals of heat treatment at temperature $900^{\circ} \mathrm{C}$. In Tab. 3 are then summarized magnitudes of individual thicknesses both for surface layer and for diffuse layer which were measured in the individual samples of testing material.

From the chemical analysis was determined that layer consists mainly from aluminium and silicon. Trace iron content that was found is probably from the basic material [9].

By EDX analysis was determined that diffuse layer consists mainly from iron and oxidation layer consist from compounds of aluminium and iron [9].

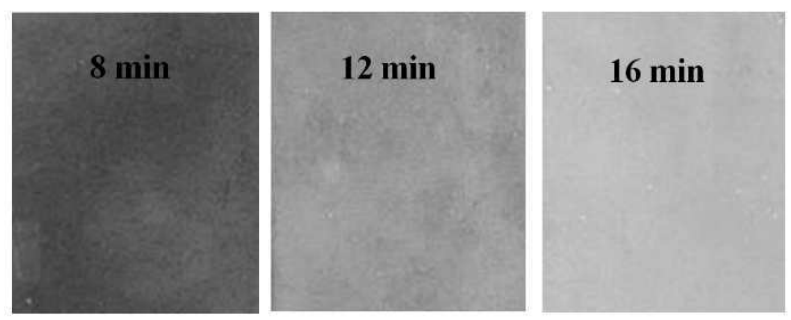

Fig. 5 Color shades of surface layer after heat treatment $900^{\circ} \mathrm{C}$ [9] 
Tab. 3 Measured thicknesses of layers [ $\mu \mathrm{m}]$ [9]

\begin{tabular}{|c|c|c|c|}
\hline $\begin{array}{c}\text { Heat treatment - time } \\
\text { in furnace [min] }\end{array}$ & $8 \mathrm{~min}$ & $12 \mathrm{~min}$ & $16 \mathrm{~min}$ \\
\hline Color shade of layer & $\begin{array}{c}\text { Dark } \\
\text { blue }\end{array}$ & $\begin{array}{c}\text { Blue- } \\
\text { grey }\end{array}$ & Grey \\
\hline $\begin{array}{c}\text { Thickness of surface } \\
\text { layer [ } \mu \mathrm{m}]\end{array}$ & $35 \pm 2$ & $36 \pm 5$ & $38 \pm 5$ \\
\hline $\begin{array}{c}\text { Thickness of diffuse } \\
\text { layer }[\mu \mathrm{m}]\end{array}$ & $9 \pm 2$ & $12 \pm 1$ & $15 \pm 2$ \\
\hline
\end{tabular}

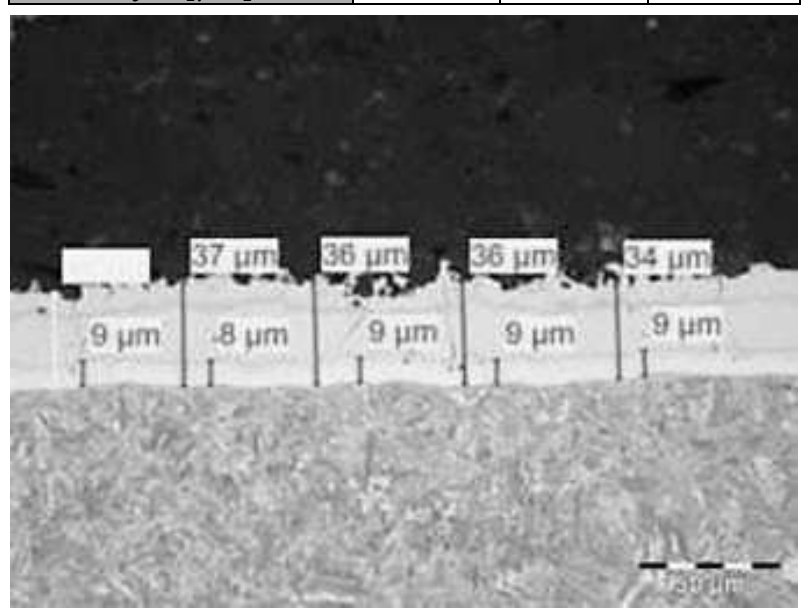

Fig. 6 Measurement of surface and diffuse layer thickness, before heat treatment (500x) [9]

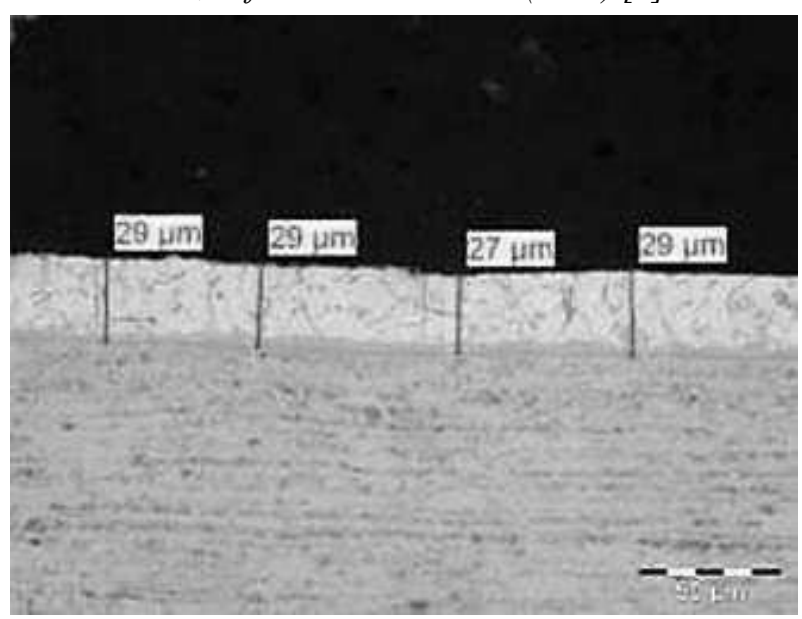

Fig. 7 Measurement of surface and diffuse layer thickness after heat treatment as $8 \mathrm{~min}, 900^{\circ} \mathrm{C}(500 x)$ [9]

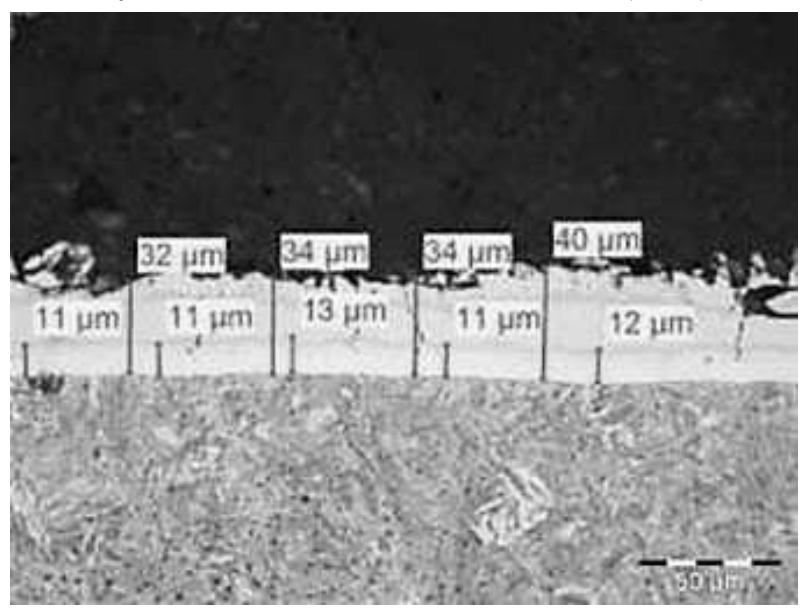

Fig. 8 Measurement of surface and diffuse layer thickness after heat treatment as $12 \mathrm{~min}, 900^{\circ} \mathrm{C}(500 x)$ [9]

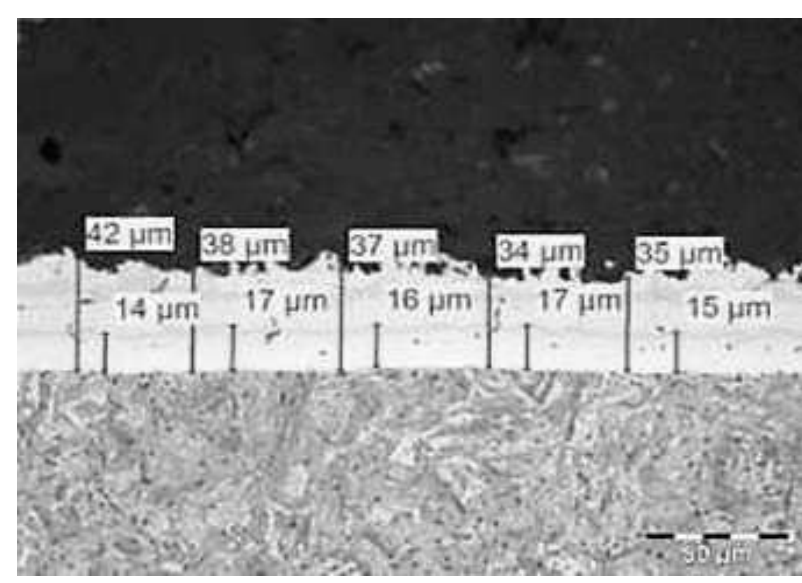

Fig. 9 Measurement of surface and diffuse layer thickness after heat treatment as $16 \mathrm{~min}, 900^{\circ} \mathrm{C}(500 x)$ [9]

In Fig. 6 are shown results from measurement the surface layer as $27 \pm 3 \mu \mathrm{m}$ (i.e. $\min 24 \mu \mathrm{m}$ and $\max 30 \mu \mathrm{m}$ ) before the heat treatment and in Fig. 7 after heat treatment $(8 \mathrm{~min})-$ in this case is thickness of surface layer $35 \pm 2$ $\mu \mathrm{m}$ and thickness of diffuse layer is $9 \pm 2 \mu \mathrm{m}$.

In Fig. 8 are shown these results after heat treatment for $12 \mathrm{~min}$. In this case were measured following thicknesses: surface layer $36 \pm 5 \mu \mathrm{m}$ and diffuse layer $12 \pm 1$ $\mu \mathrm{m}$. Fig. 9 shows these results after heat treatment for 16 min with the following thicknesses: surface layer $38 \pm 5$ $\mu \mathrm{m}$ and diffuse layer $15 \pm 2 \mu \mathrm{m}$.

\section{Conclusion}

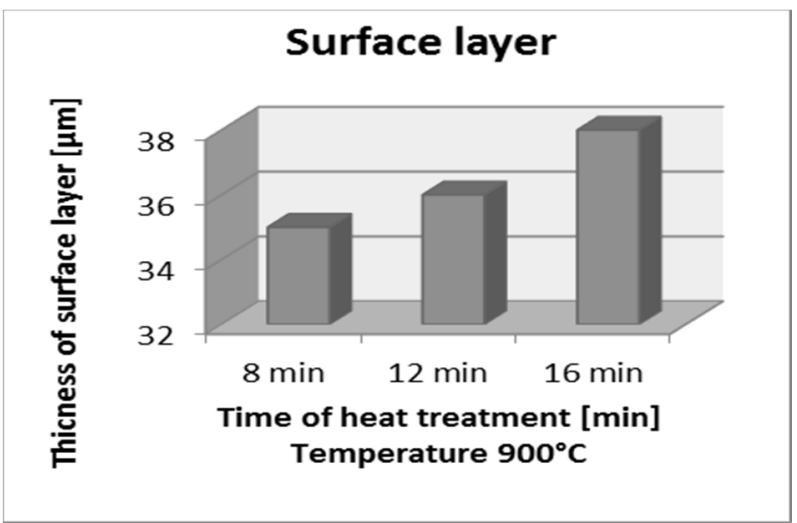

Graph 1 Thickness of surface layer in dependence on time of heat treatment [9]

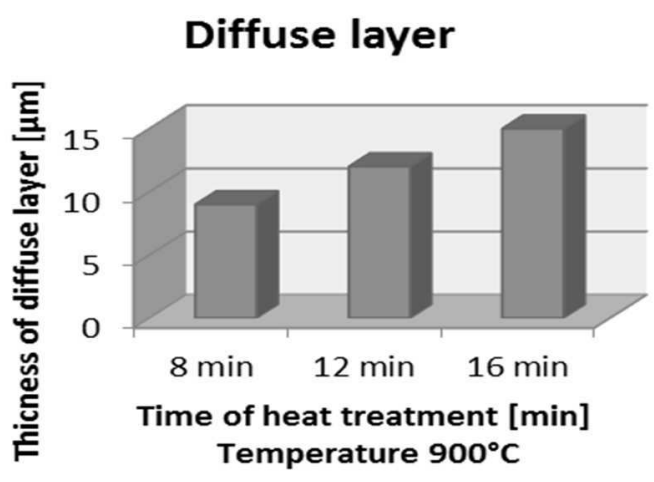

Graph 2 Thickness of diffuse layer in dependence on time of heat treatment [9] 
From the results summarized in Tab. 2 is obvious that time in furnace influences appearance and also surface layer properties. The longer time in furnace, the thicker diffuse layer. Appearance of the surface layer is stained into grey as can be seen in Fig. 5. The total coating thickness changed only slightly. From the measurement was determined that protective layer total thickness is very similar at every heat treatment intervals. Slight dissimilarity can be found at heat treatment $8 \mathrm{~min}$ where upper range of surface layer dimensions $(37 \mu \mathrm{m})$ is lower comparing to the other times of used heat treatments - resp. by $4 \mu \mathrm{m}$ for $12 \mathrm{~min}$ and by $6 \mu \mathrm{m}$ for $16 \mathrm{~min}$ heat treatment.

On the other hand, the biggest difference was measured at diffuse layer thickness where it changed for the individual heat treatment intervals. The longer heat treatment time, the higher increase of diffuse layer thickness. Difference between heat treatment of 8 and $12 \mathrm{~min}$ is in light of mean value about $2 \mu \mathrm{m}$. The bigger difference in the diffuse layer thickness was measured between intervals 12 and $16 \mathrm{~mm}$. In this case is difference between diffuse layers thicknesses in light of the maximal value even $4 \mu \mathrm{m}$. Based upon the experimental measurement was proved that there is expressive increase of diffuse layer thickness in dependence on longer time in furnace.

In Graph 1 is shown the change of the total surface layer thickness in dependence on time of heat treatment and in Graph 2 is displayed the change of the diffuse layer thickness also in dependence on time of heat treatment.

Moreover, there was determined that with the time of heat treatment is also connected the color shadow of sheet surface (see Fig. 5). At the lower time of heat treatment ( $8 \mathrm{~min}$ ) is color shadow of sheet dark blue, after $12 \mathrm{~min}$ in the furnace has the sheet blue-grey color and after 16 $\mathrm{min}$ is its color grey.

Color shadows of sheets are important for the basic analysis of the heat treatment. Due to the surface layer color is possible to approximately identify the time of material in furnace during heat treatment. This fact is mainly important for the welding of ultra-high strength sheets. Sheets which are placed in furnace for longer time have lower weldability.

\section{Acknowledgement}

This publication was written at the Technical University of Liberec (TUL) as part of the Student Grant Contest "SGS 21122" with the support of the Specific University Research Grant, as provided by the Ministry of Education, Youth and Sports of the Czech Republic in the year 2018.

\section{References}

[1] CHEN, G.A., SHI, M.F.A, TYAN, T.B. (2012) Optimized AHSS Structures for Vehicle Side Impact .In: SAE International Journal of Materials and Manufacturing. Volume 5, Issue 2, pp. 304313, ISSN: 19463979, SAE International

[2] KUČEROVÁ, L, BYSTRIANSKÝ, M., JENÍČEK, Š., FRANCISKO, P. (2017) Effect of deformation conditions on microstructure and mechanical properties of low alloyed steel. In: Manufacturing Technology, Volume 17, Issue 5, pp. 752-756, ISSN: 12132489, Publisher: Univerzita J. E. Purkyne

[3] VOTAVA, P. (2015) Odporové svařováni martenzitických oceli s variantním tepelným zpracováním. Diplomová práce, ČVUT Praha, FS [online] [cit. 2018-06-03] https://dspace.cvut.cz/bitstream/handle/10467/63565/F2-DP-2015-Votava-PavelDP\%20Pavel\%20Votava.pdf? sequence $=1$

[4] YAAKOB, K.I.,ISHAK, M.,IDRIS, S.R.A.,AIMAN, M.H.,QUAZI, M.M. (2018) Characterization of heat-treated gas metal arcwelded boron steel sheets. In: International Journal of Advanced Manufacturing Technology. Volume 94, Issue 1-4, pp. 827-834, ISSN: 02683768, Publisher: Springer London

[5] Karoserérie nového Audi A8 [online] [cit. 201806-03] http://www.auto.cz/karoserie-novehoaudi-a8-hlinik-na-ustupu-105526

[6] Extract from the product catalogue. Arcelor Mittal [online] [cit. 2018-06-03] http://automotive.arcelormital.com/saturnus/sheets/ArcelorMittal\%20Automotive $\% 20$ product $\% 20$ offer\%20EN.pdf

[7] TL 4225 (2016) Alloyed Quenched and Tempered Steel for Press Quenching - Uncoated or PreCoated: Material Requirements for Semi-Finished Products and Components.

[8] BUBLÍKOVÁ, D., MAŠEK, B., VOREL, I., JENÍČEK, S. (2017) Stability of retained austenite in high-strength martensitic steels with low Ms temperature. In: Manufacturing Technology. Volume 17, Issue 4, pp. 428-433, ISSN: 12132489 , Publisher: Univerzita J. E. Purkyne

[9] BAŠUS, M. (2017) Pevnost lepených spojů bórem legovaných ocelí s povlakem.. Diplomová práce, Technická univerzita v Liberci, FS

[10] ZHAO, J., JIANG, Z. (2018) Thermomechanical processing of advanced high strength steels. Progress in Materials Science. Volume 94, pp. 174242, ISSN: 00796425, Publisher: Elsevier Ltd

[11] HANUS,P., SCHMIDOVÁ,E. (2016) Influence of the welding process on the martensitic and dual phase high strength steels.In: Manufacturing Technology, Volume 16, Issue 4, pp. 702-707, ISSN: 12132489, Publisher: Univerzita J. E. Purkyne 